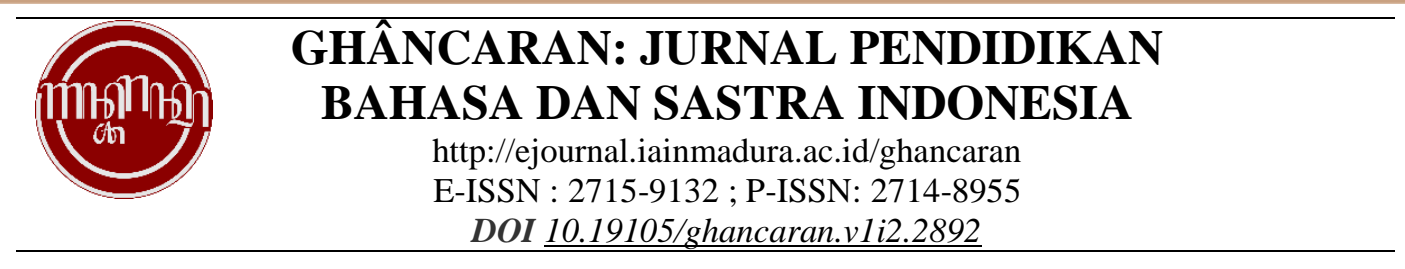

\title{
Tokoh Diar dalam Novel Rembang Jingga Karya Tj Oetoro dan Dwiyana Premadi (Kajian Feminisme Radikal Kate Millet)
}

\author{
Taufik Arifudin* \& Edi Susanto** \\ * Tadris Bahasa Indonesia, IAIN Madura \\ ** Tadris Bahasa Inggris, IAIN Madura \\ Alamat surel: taufikarid20@gmail.com
}

\begin{tabular}{ll}
\hline \hline & Abstract \\
\hline Keywords: & The Rembang Jingga novel by Tj Oetoro and Dwiyana Premadi is \\
Feminism; & very intering
\end{tabular}
very interesting to study because it contains a lot of motivation by the characters in it, especially in the character named Diar. Kate Millet's radical feminism movement can be found in the novel Rembang Jingga by $\mathrm{Tj}$ Oetoro and Dwiyana Premadi through a character named Diar who tells of his life being forced into prostitution by his own biological father, and struggling to get out of his father's house and family. So from that formulation of the problem in this study. How the Radical Femenism of Diar Figures in Rembang Jingga Novel by Tj Oetoro and Dwiyana Premadi. This study uses a descriptive qualitative approach and type of literature. Data sources were obtained from Rembang Jingga novels by $\mathrm{Tj}$ Oetoro and Dwiyana Premadi. The data taken is in the form of words, sentences, and quotes from dialogues related to radical femenism according to Kate Millet. The majority of data is taken from Diar figures. While checking the validity of the data is done through increasing perseverance.

\section{Abstrak:}

Kata Kunci:

Radikal;

Novel.
Novel Rembang Jingga karya Tj Oetoro dan Dwiyana Premadi menarik untuk diteliti karena mengandung nilai kesetaraan gender oleh tokoh-tokoh yang berada di dalamnya, terutama dalam tokoh Diar. Gerakan feminism radikal Kate Millet dapat ditemukan dalam novel Rembang Jingga karya Tj Oetoro dan Dwiyana Premadi melalui tokoh Diar. Tokoh Diar dipaksa melacur oleh ayah kandungnya sendiri dan berjuang untuk keluar dari rumah dan sekapan ayahnya. Penelitian ini bertujuan untuk mengungkapkan bentuk femenisme radikal tokoh Diar dalam novel Rembang Jingga karya Tj Oetoro dan Dwiyana Premadi. Penelitian ini menggunakan metode kualitatif dengan pendekatan deskriptif dan jenis kepustakaan. Sumber data diperoleh dari novel Rembang Jingga Karya Tj Oetoro dan Dwiyana Premadi. Data yang diambil berupa kata, kalimat, dan kutipan dialog yang berkaitan dengan femenisme radikal menurut Kate Millet. Data tersebut mayoritas diambil dari tokoh Diar. Pengecakan keabsahan data dilakukan melalui peningkatan ketekunan.. Feminisme radikal yang digagas Katte Millet relevan dengan novel Rembang Jingga karya Tj Oetoro dan Dwi Premadi. Hal itu tidak terlepas dari perjuangan tokoh Diar dalam melawan kehendak ayahnya untuk menjadi pelacur. 


\section{PENDAHULUAN}

Karya sastra pada hakikatnya merupakan sebuah cerminan dari keadaan sosial masyarakat. Karya sastra menjadi salah satu hasil aktivitas seni yang diciptakan untuk mencatat dan mengkomunikasikan fenomena yang terjadi di dalam masyarakat. Pengarang atau penyair mengkonstruksi karya sastra yang berbentuk fiksi (cerpen, novel, dan drama) lazimnya berdasarkan persoalan yang ditampilkan oleh pengarang berdasarkan hasil dari pengalaman kehidupan nyata sehari-hari. Melalui karya sastra, pembaca (masyarakat) akan menemukan kembali sejumlah peristiwa, gejala sosial, budaya, dan politik yang pernah terjadi di masyarakat pada masa tertentu.

Dalam penciptaan karya sastra, pengarang merekam gejala-gejala sosial yang terjadi dalam masyarakat yang menjadi inspirasi lahirnya sebuah karya sastra. Segala fenomena dan permasalahan dalam masyarakat dijadikan objek dalam dunia sastra. Karya sastra dapat dipandang sebagai gejala sosial yang mencerminkan kehidupan. Hal itu berarti bahwa sastra menggambarkan kenyataan yang terjadi dalam kehidupan masyarakat. Hal tersebut membuat lingkungan sosial yang terdapat di sekeliling pengarang sangat mempengaruhi lahirnya sebuah karya sastra (Luxemburg, 1986:23).

Salah satu karya sastra yang sangat populer terutama dikalangan anak muda adalah novel. Novel merupakan salah satu karya sastra berbentuk prosa. Sebagai karya sastra novel diciptakan oleh pengarangnya untuk dapat memberikan kenikmatan, kesenangan dan manfaat bagi pembacanya. Novel tidak dapat dibaca sekali duduk, karena novel berisi tentang permasalahan karakter dan kehidupan tokoh dalam perjalanan waktu. Salah satu novel yang menarik untuk dibaca dan dikaji ditataran akadeik, terutama tentang perjuangan kesetaraan gender ialah novel Rembang Jingga karya Tj Oetoro dan Dwi Premadi.

Novel Rembang Jingga menceritakan tentang perjuangan hidup tokoh perempuan yang dipaksa ayahnya menjadi pelacur dan melakukan perbuatan intim dengan seorang laki-laki di sebuah hotel. Perjalanan panjang yang harus ditempuh oleh Diar dalam kehidupannya. la bahkan menjadi penjaga warung nasi di Tegal sampai akhirnya ke Jakarta, dan memutuskan untuk minggat dari tempat prostitusi di pantura. Dalam novel Rembang Jingga terdapat empat orang perempuan yang mempunyai masalah masing-masing. Dari empat tokoh tersebut, tokoh Diar menjadi tokoh yang mendominasi dan menonjol dalam perjuangan hidupnya. Perjuangan hidup tokoh Diar dalam novel Rembang Jingga memotivasi dan memberikan nilai kepada pembaca bahwa jangan mudah tergoda oleh kekuasaan, uang, dan dunia yang membuat seorang gadis perempuannya untuk menjadi pelacur dan berpakaian yang seksi-seksi.

Wanita dipandang sebelah mata dan hanya mempunyai peran dalam ranah tertentu saja yaitu, kasur, dapur dan rumah. Budaya patriarki memarginalkan wanita yang begitu terbatas. Tubuh wanita diartikan sebagai sebuah kecantikan. Ukuran kecantikan seorang wanita diukur dari bentuk tubuh sedangkan akhlak hal yang sekian. Wanita dianggap pengacu dan pembuat masalah. Pandangan-pandangan tersebut memunculkan perlawanan dengan gerakan feminism. Gerakan feminisme ini menjadi suatu gerakan kaum perempuan yang menuntut persamaan hak sepenuhnya antara kaum perempuan dan laki-laki. Kemunculan feminisme diawali dangan gerakan emansipasi perempuan, yaitu proses pelapasan diri kaum perempuan dari kedudukan soisal ekonomi yang rendah serta pengkekangan hukum yang membatasi kemungkinan-kemungkinan untuk berkembang dan untuk maju (Sugihastuti, 2016:61).

Teori feminis dibedakan dua istilah yaitu emansipasi dan gender. Emansipasi berasal dari kata emancipatio (Latin) yang berarti persamaan hak dalam berbagai aspek kehidupan, gender didefinisikan sebagai lawan seks. Pokok permasalahan feminis dan gender adalah persamaan hak. Gender bersifat psikologis cultural, sebagai perbedaan antara masculine-feminine, sedangkan seks bersifat fisiologis, secara kodrati, sebagai perbedaan antara male-famela (Ratna, 2004:219). Perempuan dalam pandangan 
feminisme mempunyai aktivitas dan inisiatif sendiri untuk memperjuangkan hak dan kepentingan tersebut dalam berbagai gerakan (Rokhmansyah, 2014:130).

Salah satu gerakan feminis dipelopori oleh Kate Millet dengan paham feminisme radikal. Gerakan feminisme radikal mendasarkan pahamnya pada strukturalisme politik. Gerakan ini dibangun berdasarkan asumsi bahwa hubungan antara manusia atau antarkelompok pada dasarnya merupakan hubungan saling menguasai dan mengendalikan kekuasaan yang menentukan. Feminisme radikal berpendapat bahwa fungsi reproduksi perempuan juga merupakan basis penindasan perempuan reproduksi merupakan konsep yang mempunyai dua arti. Pertama, proses pengembangbiakan dan pemeliharaan rumah tangga serta sosialisasi anak-anak. Kedua, proses-proses reproduksi biologis dan seksualitas yang dipengaruhi secara sosial. Kedua hal tersebut saling berkaitan dengan pengendalian laki-laki terhadap reproduksi biologis perempuan.

Dasar ketidakadilan terhadap perempuan adalah patriarkat yang dianggap sebagai masalah universal dan mendahului segala bentuk penindasan. Patriarkat adalah sebuah sistem otoritas yang berdasarkan pada kekuasaan lelaki yang juga menyusup ke institusi-institusi sosial, politik, dan ekonomi. Patriarkat muncul bersamaan dengan sistem ekonomi yang ada dalam setiap formasi masyarakat (Feoddalisme, kapitalisme, ataupun sosialsme) (Kusharyanto, 2009:141-142). Pemimpin institusi patriarki adalah keluarga. Dalam organisasi tersebut terdapat struktur sosial dan individu, misalnya keluarga memiliki pengaruh besar dalam mengontrol dan melakukan penyesuain terhadap lingkungan sekitar aturan-aturan kecil dalam organisasi kecil tersebut sudah dapat dikatakan sebagai politis. Maskipun dalam sistem sosial patriarki terdapat pemimpin dan rakyat yang jelas, perempuan cendrung menjadi kaum yang diatur oleh keluarga atau pemimpi yang lain (Millet, 1970:33).

Millett menyatakan bahwa pornografi seringkali berfungsi dengan cara yang hampir sama dengan iklan. Tubuh langsing yang sempurna dari para model, yang memenuhi Cover Vogue, menjadi standart bagi seluruh perempuan. Tidak seorang pun harus mengartikulasi hukum yang eksplisit (Tong, 1998: 73-76). Dalam pandangan feminisme radikal, Millet (1970) menyampaikan gagasan agar perempuan mendapatkan hak yang sama denga laki-laki, perempuan juga harus mencapai apa yang laki-laki bisa capai. Millet menunjukkan delapan konsep dalam teorinya, yaitu ideologis, biologis, sosiologis, kelas, ekonomi \& pendidikan, paksaan, antropologis, serta psikologis.

Secara ideologis, status politik seksual telah mendapat izin untuk mengakui anggapan superioritas laki-laki, yakni laki-laki kaum superioritas dan perempuan sebagai kaum iforior.Hal yang paling bersangkutan dengan farmasi kemanusiaan tersebut ialah garis streotip kategori gender yakni maskulin dan feminisme. Ideologi patrikal, menurut Millet, membesar-besarkan perbedaan biologis antara laki-laki dan perempuan, dan memastikan bahwa laki-laki memunyai peran yang maskulin dan dominan, sedangkan perempuan selalu memunyai peran yang subordinat atau feminin. Ideoligi tersebut begitu kuat, bahkan laki-laki dapat memperoleh persetujuan apapun dari perempuan yang mereka apresi.Biasanya mereka melakukan hal itu melalui satu instansi akademik, gereja atau keluarga yang masing-masing menjelaskan dan menegaskan subordinasi perenpuan terhadap laki-laki yang berakibat bagi kebanyakan perempuan untuk menginternalisasi rasa inferioritas terhadap laki-laki.

Status perempuan dalam patriarki berpotensi membingungkan status seksual seiring mengalami kebingungan atas variabel kelasnya. Dalam sebuah masyarakat yang menilai status berdasarkan atas ekonomi, sosial dan pendidikan, memungkinkan bahwa perempuan bisa berada pada posisi lebih tinggi dari laki-laki.pada kelas sosial yang lebih tinggi dengan cara sungguh-sungguh dan berusaha (Millet, 1970:36). Dalam persoalan ras, suatu sistem kasta yang menggolongkan tiap individu dengan kelas 
mengajak rakyat memiliki semangat hidup yang lebih tinggi untuk mendapatkan kelas sosial yang lebih tinggi pula.

Millet (1970:43) mengungkapkan bahwa sejatinya manusia tidak membiasakan diri untuk mengasosiasi patriarki dengan paksaan. Secara historis, sistem patriarki memiliki instusi penekanan melalui sistem legal mereka. Contohnya pada sistem patriarki yang ada dalam islam, telah mengimplementasi larangan melawan legimitasi atau ekonomi seksual dengan kalimat mematikan. Bahwa perempuan tunduk seutuhnya kepada laki-laki dengan catatan suami cacat lahir batin. Paksaan patriarki juga mempercayakan pada kekerasan seksual yang istimewa dalam karakter dan menyadari secara penuh dalam aksi perkosaan. Hal tersebut dikarenakan kaum laki-laki mengangap kaum perempuan sebagai kaum yang subordinat, juga karena kekuatan fisik mereka yang lebih kuat. Kepercayaan tersebut menimbulkan mitos kebijaksaan secara politik karakter tentang keyakinan tentang perempuan. Nada patrirki yang kosisten dai asumsi bahwa biologis perempuan berbeda dalam pemisahannya. Di bawah patriarki, perempuan tidak dapat mengembangkan sendiri simbol-simbol yang mereka artikan.

Aspek-aspek patriarki sudah dideskripsikan dalam bentuk pengaruh psikologis dari kedua jenis kelamin. Akibat secara prinsipal ialah interioritasi ideologi patriarki. Status, emosi, dan peranan marupakan sistem nilai dengan percabangan psikologis yang tak ada habisnyauntuk setiap jenis kelamin. Perkawinan patriarki dan keluarga dengan bagian-bagian besar dalam penyelengaraan mereka. Laki-laki menduduki posisi ekonomi yang superior sedangkan perempuan sebagai kaum inferior yang dimplikasinya terkubur (Millet, 1970: 54). Sebagai perempuan dalam patriarki, kelompok yang termaginalkan, mereka juga dianggap sebagai kelompok minoritas. Anggapan tersebut dikarenakan fisik atau karakteristik budaya mereka sedikit berbeda dengan yang lainnya. Dapat dikatakan, patriarki adalah senjata psikologis terhebat karena mampu mempengaruhi psikis seorang secara langsung ataupun tidak langsung.

Feminisme aliran radikal banyak dikritik karena dianggap terlalu ekstrim. Dikatakan bahwa teori feminisme radikal terlalu tertumpu pada orientasi biologis dan lupa bahwa ada pengaruh kultur dalam pembentukan konsep gender. Hal ini tentunya tidak sesuai dengan kenyataan yang ada karena keberadaan pria tetapi diperlukan dalam segala aspek kehidupan untuk menghidupkan keseimbangan sosial. Menurut Millet dalam feminisme radikal terdapat konsep yang tentunya berkaitan dengan kemandirian dan perjuangan dalam rangka menuntut hak-hak dan martabat perempuan yang berkaitan juga dengan dengan kekerasan yang dialami tokoh. Millet melihat perempuan diprogram dalam kasus seperti kasta yang dipertahankan melalui paksaan atau penanaman ieologi. Paksaan tersebut memkasakan perempuan untuk tetap pada tempatna, termasuk kekekajaman aneh yang mengikat seperti kerudung, perkosaan, sadis.

Dalam pandangan Islam derajat manusia itu sama tidak ada bedanya antara lakilaki dan perempuan karena pada hakikatnya dalam pandangan Islam yang membedakan manusia itu hanyalah ketakwaannya seperti yang dijelaskan dalam Surat Al-Hujarat Ayat 13.

$$
\text { يا أيها الناش إنا خلقناكم من دكر و أنش وجعلناكم شعوبا وقبائل لنعارفوا إن أكرمكم عند الله اتقاكم إن الله عليم خبير }
$$

Artinya: "Wahai Manusia! Sungguh, kami telah menciptakan kamu dari seorang laki-laki dan seorang perempuan, kemudian kami jadikan kamu berbangsa-bangsa dan bersuku-suku agar kamu saling mengenal. Sesungguhnya,yang paling mulia diantara kamu di sisi Allah ialah orang yang paling bertakwa. SungguhAllah maha mengetahui mahateliti" (Depag, 2016: 518).

Gerakan feminisme yang dapat ditemukan dalam novel Rembang Jingga melalui tokoh Diar. Dalam kehidupannya, Diar berjuang untuk melawan kehendak ayah 
kandungnya yang memaksa untuk memelacur. la terus berjuang untuk keluar dari rumah dan sekapan ayahnya. Tidak tahan dipaksa jadi pelacur oleh ayahnya, Diar memutuskan minggat dari tempat prostitusi di Pantura.Jalan panjang dan berliku harus ditempuh Diar, bahkan menjadi pelayan warung nasi di Tegal sampai akhirnya ke Jakarta. Hingga takdir hidup membuat Diar harus pulang lagi ke Rembang. Setelah menikah, Ires berharap mendapatkan kasih sayang dari suami yang sangat dicintainya. Namun, yang ia dapatkan hanya kekerasan fisik dan mental. Pertemuan Ires dengan Diar memberi harapan baru baginya.Ires mengikuti ajakan Diar untuk kabur dari rumah. Ires yang lugu dan berhati lembut tidak mengira suaminya menyimpan dendam dan bertekad mengejarnya kemana pun. di Rembang keempatnya bertemu, bersahabat, dan akhirnya malapetaka yang timbul membuat salah satu dari mereka harus membayar mahal.

\section{METODE}

Penelitian ini menggunakan metode pendekatan deskriptif kualitatif dengan jenis penelitian kepustakaan. Penelitian ini yang bertujuan untuk menggambarkan secara utuh dan mendalam tentang realitas sosial dan berbagai fenomena yang terjadi di masyarakat yang menjadi subjek penelitian sehingga tergambarkan ciri, karakter, sifat, dan model dari fenomene tersebut (Sanjaya, 2013:47). Sumber data penelitian ini adalah novel yang berjudul Rembang Jingga Karya Tj Oetoro dan Dwiyana Premadi, dan sumber data penunjang dalam landasan teori berupa buku-buku tentang kajian femenisme. Data dalam penelitian berupa kata, kalimat, dan kutipan dialog yang berkaitan dengan femenisme radikal Kate Millet.Dta tersebut mayoritas diambil dari tokoh perempuan yang bernama Diar.

Teknik pengumpulan dan analisis data dalam penelitian ini dilakukan dengan cara berikut ini. (1) Membaca novel secara berulang-ulang (lebih kurang 3 kali) untuk mendapatkan pemahaman mendalam. (2) Mengidentifikasi percakapan tokoh Diar dalam Novel Rembang Jingga Kaya Tj Oetoro dan Dwiyana Premadi yang termasuk dalam feminisme radikal Kate Millet. (3) Mengklasifikasi data feminisme radikal Kate Millet tokoh Diar dalam Novel Rembang Jingga Kaya Tj Oetoro dan Dwiyana Premadi. (4) Memberikan kesimpulan tentang feminisme radikat Kate Millet tokoh diar dalam Novel Rembang Jingga Kaya Tj Oetoro dan Dwiyana Premadi. Pembacaan dan penafsiran menjadi peran penting. Hubungan pembaca dengan teks sangat menentukan hubungan terwujud dalam konteks pembacaan (Susanto, 2017)

Dalam penelitian ini digunakan teknik-teknik untuk mengukur keabsahan temuan data. Teknik dalam mengukur keabsahan data menggunakan ketekunan/keajegan pengamatan. Peneliti mencari secara konsisten interpretasi dengan berbagai cara dalam kaitan dengan proses analisis yang konstan atau tentatif. Ketekunan pengamatan bermaksud menemukan ciri-ciri dan unsur-unsur dalam situasi yang sangat relevan dengan persoalan atau isu yang sedang dicari dan kemudian memusatkan diri pada halhal tersebut secara rinci (Moleong, 2017:329).

\section{HASIL DAN PEMBAHASAN}

Kajian tentang tokoh Diar dalam Novel Rembang Jingga Kaya Tj Oetoro dan Dwiyana Premadi ini dianalisis berdasarkan perspektif feminisme radikat menurut Kate Millet, yaitu ideologis, biologis, sosiologis, kelas ekonomi dan pendidikan, paksaan, antropologis (mitos dan kepercayaan), psikologis. Pembahasan mengenai hal tersebut akan dipaparkan sebagai berikut. 


\section{Ideologis Tokoh Diar dalam Novel Rembang Jingga karya Tj Oetoro dan Dwiyana Premadi}

Secara ideologis, status politik seksual telah mendapat izin untuk mengakui anggapan superioritas laki-laki, yakni laki-laki kaum superioritas dan perempuan sebagai kaum iforior. Hal yang paling bersangkutan dengan farmasi kemanusiaan tersebut ialah garis streotip kategori gender yakni maskulin dan feminim (Millet, 1970:26). Berdasarkan nilai dan kebutuhan kelompok yang dominan. Secara umum kaum laki-laki selalu dianggap memiliki sifat agresuf, memiliki kecerdasan yang lebih tinggi, kuat dan suaranya patut didengar, sedangkan perempuan bersifat pasif serba tidak tahu atau bodoh, patuh, baik dan tidak berguna.

Hal tersebut semakin lengkap dengan adanya faktor kedua yakni peranan jenis kelamin yang menurunkan nilai dari tingkah laku untuk setiap jenis kelamin. Perempuan biasanya memunyai peran yang terbatas karena peran biologisnya. Ideologis tokoh yang dimiliki Diar yakni berani dan merencanakan untuk bebas dari siksaan ayah yang tega menjual anaknya sendiri kepada lelaki hidung belang. Dengan ide dan tekad yang besar Diar mengambil keputusan untuk kabur dari rumahnya dan menunjukan bahwa perempuan itu bisa berfikir dan bebas dari tekanan apapun. Hal ini dapat dibuktikan dalam kutipan berikut.

Diar bertekad akan mengubah penampilan wajahnya.Bayangan-nya pada rambut pendek dan kacamata.Begitu punya uang, Diar bermaksud memotong rambut dan membeli kacamata. Ketakutan muncul lagi membayangkan bila dia bertemu dengan lakilaki bekas pelanggannya, lalu membocorkan rahasia bahwa dia pernah jadi lonte (Oetoro \& Dwiyana, 2015: 81).

Kutipan data di atas menunjukkan bahwa Diar memiliki ideologis tinngi.Hal itu berkaitan dengan teori yang disampaikan Kate Millet bahwasanya tidak hanya laki-laki yang bisa memiliki kecerdasan yang lebih tinggi, kuat dan suaranya patut didengar.Wanitapun juga memiliki sifat seperti itu, seperti halnya yang dilakukan Diar. Dengan tekad yang bulat Diar merubah penampilannya hanya karena tidak mau ada satu orang pun yang mengenalnya terutama pelanggan-pelanggannya waktu dia pernah menjadi lonte.Dan Diar inginhidup bebas tanpa ada lagi paksaan dari seorang laki-laki yang bejat.

Selain tokoh Diar ada juga tokoh perempuan bernama Ires yang mengalami kekerasan rumah tangga disiksa suaminya sendiri. Sebagai seorang teman Diar tidak rela melihat seorang perempuandisiksa oleh laki-laki siapapun, maka dari itu Diar memberikan ide dan mengajak Ires untuk kabur dari rumahnya seperti kutipan Berikut:

\footnotetext{
"Mendengar cerita Ires, Diar langsung mengajaknya pergi dari rumah itu. Pertamapertama ires menolak, takut herlambang akan mengetahui keberadaanya. Sealain itu dia tidak berani karena dia tidak memiliki apa-apa untuk hidup sendiri."

"Mbak Ires, lihat aku. Aku juga minggat dari rumah ngak punya apa-apa.Aku bahkan sendiri banget. Kalau mbak ires pergi sekarang, kanada aku.ayolah! kehidupanmu ngak sehat disini. Aku ngak rela kamu dapat perlakuan seperti ini, ayolah mbak," Pinta Diar (Oetoro \& Dwiyana, 2015: 89).
}

Kutipan data di atas merupakan Ideologis tokoh Diar dan Ires. Hal itu berkaitan dengan teori yang disampaikan Kate Millet bahwasanya tidak hanya laki-laki yang bisa memiliki kecerdasan yang lebih tinggi, kuat dan suaranya patut didengar.Wanitapun juga memiliki sifat seperti itu, seperti halnya yang dilakukan Diar.Diarmengajak Ires kabur dan memberikan cara supaya bebas dari siksaan suaminya.hal itu menunjukan bahwa perempuan bisa nekad bila mengalami penyiksaan dari seorang laki-laki dengan kekuatan dan ide yang mereka miliki. 


\title{
Biologis Tokoh Diar dalam Novel Rembang Jingga karya Tj Oetoro dan Dwiyana Premadi
}

Berdasarkan ilmu pengetahuan dan analisis dari psikolonalisis ada perbedaan biologis di antara kedua jenis kelamin, misalnya pandangan dalam kepercayaan patriarki, prilaku populer dan derajat atau kedudukan. Oleh karena itu, dalam mengakui pembentukan perilaku tidak ada yang lebih baik dari yang dilakukan oleh alam. Kurangnya suatu bukti tentang adanya perbedaan sosial dari patriarki (status, peranan dan emosi) adalah keaslian psikis seorang, tetapi kita juga kesulitan dalam menilai perbedaan itu. Seks memang berbeda dengan gender. Seks secara biologis dapat dilihat oleh kasat mata memang beda yakni jenis kelamin laki-laki dan perempuan. Sedangkan gender dapat dilihat secara kultural dan diajarkan melalui sosialisasi yakni sikap maskulin dan feminin (Millet, 1970:27).

Biologis yang terjadi pada tokoh yang bernama Diar, yang dulunya mempuyai psikologis ketakutan, kecemasan akan hal yang terjadi pada dirinya, tetapi sekarang berubah menjadi tekad yang besar karena rasa ingin bebas dan aman dari jeratan ayah kandungnya yang kejam itu. Hal ini dapat dibuktikan pada kutipan sebagai berikut:

\begin{abstract}
"Diar tercenung beberapa detik. Kotak itu! Kotak itu masih disitu tertututp tapi belum digembok lagi.Tak tahu mendapat keberanian dari mana, Diar membuka kotak itu.Diraupnya isinya.Entah berapa, terlihat lembaran sepuluh ribuan dan beberapa lembar ribuan.Dimasukkan begitu saja uang itu kedalam saku celananya. Cepat-cepat ditutup lagi kotak itu dalam posisi yang sama, seperti tidak berubah. Jantungnya berdegup kuat, dia deg-degan Oetoro \& Dwiyana, 2015: 67)"
\end{abstract}

Kutipan data di atas untuk memenuhi kebutuhan biologis Diar. Dia memberanikan diri mengambil uang ayahnya untuk ongkos kabur dari rumahnya. Diar yang dulunya memiliki sifat penakut kini berubah menjadi penekat karena kebutuhan biologisnya. Kesempatan Diar kabur dari rumahnya sangat besar karena yang mengantarkan ke pasar bukan Ayahnya yakni Agus tetangga Diar. Diar meninggalkan Agus ditengah keramain pasar menikung berjalan cepat menuju terminal bus untuk pergi dari rumahnya dan ingin bebas dari siksaan ayahnya.

"Diar memasuki masjid yang ditemui sesudah berjalan jauh.Setelah membersihkan diri, diar mendirikan shalat. Baru kali ini Diar sholat dengan khusuk tanpa memikirkan strategi kabur dari rumah, karena kali ini dia sudah minggat, dia sudah bebas!

Setelah solat, Diar menangis lagi, berdzikir lagi, menguatkan tekadnya untuk hidup terbebas dari paksaan bapaknya, dari perbuatan maksiat para laki-lakia bejat" (Oetoro \& Dwiyana, 2015: 75)

Kutipan data diatas menunjukan bahwa biologis Diar sudah mulai terpenuhi karena bisa kabur dari rumah dan bebas dari siksaan ayahnya. Diar bisa melaksanakan sholat dengan khusuk tanpa memikirkan strategi kabur dari rumahnya lagi. Diar terus menguatkan tekadnya untuk hidup bebas dari paksaan ayahnya yang tega menjual anak kandungnya sendiri untuk kesenagan dirinya tanpa memikirkan psikis yang dialami oleh anak kandungnya.

\footnotetext{
"Keraguan Diar menipis setelah melihat sikap Kasan yang tidak menimbulkan kecurigaan lebih lanjut bahwa dia termasuk laki-laki hidung belang yang selama ini temuinya. Dikumpulkannya keberaniannya untuk membuka percakapan, Diar ingin bisa bekerja menjadi pembantu di warung ini"

"Pak.."

Pak Kasan menole. "Ya, ada apa, Dik?"
} 


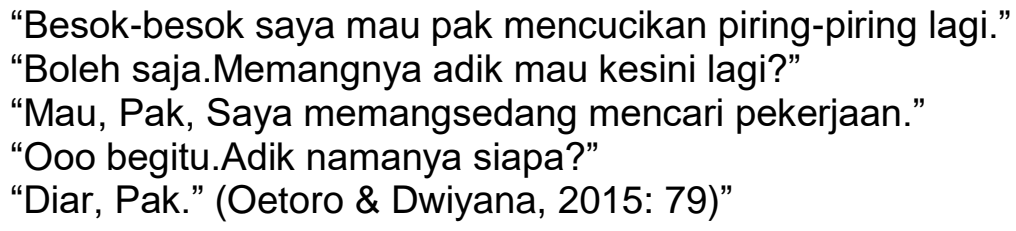

Dari kutipan data di atas keraguan terhadap bapak penjual nasi di warung itu menjadi keraguan yang baik, melihat sikap bapak tersebut tidak mengaganggu Diar. Membuat keberanian Diar semakin besar bahwa laki-laki penjual nasi di warung yang bernama Kasan ini orang baik tidak seperti laki-laki yang telah dia temui, laki-laki hidung belang yang telah menghabiskan dirinya. Diar lebih berani membuka percakapan terlebih dulu hal ini dapat dilihat bukti percakapan berikut.

Diar bersyukur bertemu dengan pak kasan yang sepertinya baik hati, terutama pada sambutnnya bagi Diar, boleh membantu diwarungnya siapa tahu Diar bisa bekerja diwarung itu dan mendapatkan upah. Diar bahagia karena setidaknya ada jalan untuk menyambung hidup (Oetoro \& Dwiyana, 2015: 81).

Kutipan data di atas untuk memenuhi kebutuha biologis tokoh Diar, Diar membantu bekerja untuk mendapatkan upah untuk menyabung hidupnya selama dia kabur dari rumah.Hal ini selaras apa yang diakatakan Kate Millet. Perempuan bisa bekerja dan menyatu dengan Alam untuk memenuhi kebutuhan hidupnya. Diar lebih merasa tenang saat berkeluh kesah mengenai hidupnya yang dijadikan pelacur oleh ayahnya sendiri kepada sahabatnya yang bernama Ires, tetapi Ires pun menceritakan kehidupanya bagaimana suaminya yang begitu kejam dan suka memukul dirinya.

\section{Sosiologis Tokoh Diar dalam Novel Rembang Jingga karya Tj Oetoro dan Dwiyana Premadi}

Pemimpin institusi patriarki adalah keluarga. Hal tersebut dapat dikatakan sebagai cermenin masyarakat atau organisasi sosial yang lebih luas. Dalam organisasi tersebut terdapat struktur sosial dan individu. Keluarga memiliki pengaruh besar dalam mengontrol dan melakukan penyesuain terhadap lingkungan sekitar aturan-aturan kecil dalam organisasi kecil tersebut sudah dapat dikatakan sebagai politis. Maskipun dalam system sosial patriarki terdapat pemimpin dan rakyat yang jelas, perempuan cendrung menjadi kaum yang diatur oleh keluarga atau pemimpin yang lain (Millet, 1970:33).

Sosiologis tokoh Diar adalah keluarga sebagai penentu hidupnya. Keluarga memiliki pengaruh besar dalam mengontrol dan melakukan penyesuain terhadap lingkungan sekitar. Sosiologis yang terdapat dalam tokoh Diar seperti Kutipan Berikut:

"Maklum sejak berwujud bayi, Diar ditinggal di desabersama Mbah. Mbah Karto, Neneknya itu adalah pengasuh yang berhati mulia di mata Diar. Dari sisi Mbah-lah Diar mendapatkan prinsip-prinsip hidup, menjaga etika, dan pendorong semangatnya menjadi manusia yang baik.Mbah juga selalu menanamkan rasa hormat kepada orangtua."

"Kamu tidak boleh membantah Bapak dan si Mbok ya, jangan nakal, yang nurut ya," Begitu nasihat si Mbah selalu, berulang-ulang kali.Itulah yang membuat dirinya tak mampu melawan kehendak ayahnya (Oetoro \& Dwiyana, 2015: 62).

Penentu kebutuhan dan kehidupan sosiologis adalah kelaurga. Mbah selaku keluarga yang mengasuh Diar dari kecil mengajarkan prinsip-prinsip hidup menjaga etika dan pendorong semangatnya menjadi manusia yang baik dan juga selalu menanamkan rasa hormat kepada orang tua. Hal tersebut berkaitan dengan teori yang disampaikan Kate Millet bahwa pemimpin institusi patriarki adalah keluarga. Keluarga menjadi cerminan masyarakat atau organisasi sosial yang lebih luas. 
"Sugeng menyuruh Diar mengikuti laki-laki berjaket hitam itu, namun dia tidak ikut bergeming diatas speda motornya sambil memegang jaket Diar. Diar ragu-ragu dan bertanya apa yang harus dialkukannya. Sugeng tidak menjawab, dia hanya memberi kode kepada Diar untuk mengikuti laki-laki itu.Diar agak tenang dengan kerelaan ayahnya.Berarti laki-laki berjaket hitam itu tidak akan mencelakannya.Ayahnya pasti percaya kepada orang itu sehingga dia merelakan anaknya mengikutinya Oetoro \& Dwiyana, 2015: 59).

Kutipan data tersebut menunjukan bahwa penentu sosiologis adalah keluarga.seperti teori yang disampaikan Kate Millet Pemimpin institusi patriarki adalah keluarga. Hal tersebut dapat dikatakan sebagai cermenin masyarakat atau organisasi sosial yang lebih luas. Dalam sistem sosial patriarki terdapat pemimpin dan rakyat yang jelas, perempuan cendrung menjadi kaum yang diatur oleh keluarga atau pemimpin yang lain. Seorang ayah menyuruh anaknya mengikuti apa yang diperintahkan meskipun dalam pekerjaan yang kotor. Sebagai seorang anak yang patuh kepada orang tua Diar tidak berani melawan dan mengikuti semua kemauanya. Seorang ayah jadi penentu terhadap kehidupan keluarga. Sebagai seorang anak dan istri mereka menurut apa yang dikatakan oleh ayahnya mereka tidak berani melawan apa yang dia inginkan meskipun itu perbuatan kotor.

\section{Kelas Tokoh Diar dalam Novel Rembang Jingga karya T.j Oetoro dan Dwiyana Premadi}

Dalam pembicaraan kelas, status perempuan dalam patriarki berpotensi membingungkan status seksual sering mengalami kebingungan atas variabel kelasnya. Dalam sebuah masyarakat yang menilai status berdasarkan atas ekonomi, sosial dan pendidikan, memungkinkan bahwa perempuan bisa berada pada posisi lebih tinggi dari laki-laki.pada kelas sosial yang lebih tinggi dengan cara sungguh-sungguh dan berusaha.

Dalam persoalan ras, suatu sistem kasta yang menggolongkan tiap individu dengan kelas, mengajak rakyat memiliki semangat hidup yang lebih tinggi untuk mendapatkan kelas sosial yang lebih tinggi pula. Artinya, semua orang bisa berada. Fungsi dari kelas atau etnis dalam patriarki, sebagai persoalan besar bagaimana ditunjukkan dengan jelas budaya umum dari supremasi maskulin menjadikan dirinya ada. Hal ini dihadapkan dengan apa yang muncul sebagai paradoks, pada strata sosial yang lebih rendah, laki-laki lebih suka menunutut hak untuk bertindak pada kekuatan seksnya. Sebenarnya ia harus lebih rendah, laki-laki lebih suka menuntut hak untuk bertindak pada kekuatan seksnya. Sebenarnya ia harus lebih sering berbagi kekuatan dengan perempuan dari kelasnya yang memiliki tendesan yang kurang untuk berterus terang melakukan dominasi patriarki. Dalam novel Rembang Jingga karya Tj Oetoro dan Dwiyana, tokoh Diar merasa berada dalam kelas yang rendah karena dia tidak sekolah tinggi dan bekas pekerja lonte atau pelacur.

"Diar tetap meragu. Baginya mas Darma adalah sosok yang patut dihormati. Dia teman mbak Karina dan orang yang pintar, "yang makan sekolahan", masak sih mau punya pacar seorang gadis desa, cucu pembantu.

"Mas, sudah pikirkan masak-masak? Kita kan dalam banyak hal berbeda, Mas. Mas Darma kan sarjana, sedangkan saya tidak pernah duduk di perguruan tinggi. Lagi pula mas kan temannya mbak Karina, sedangkan mbak Karina itu sahabatnya kak Amanda yang majikan saya, mas. Belom lagi persolan masa lalu Diar yang pernah menjadi pekerja seks. Apakah Darma mengetahuinya? 
Mungkin dari Karina. Tapi tidak mungkin Karina menceritakan aib itu. Ah. Entahlah

"Diar, dengar ya, jangan memikirkan hal itu. Manusia kan memang berbeda, saya ngak melihat itu sebagai halangan bagi kita untuk pacaran. Yang penting yang kulihat kamu orangnya mau belajar. Itu adalah kunci untuk keberhasilanmu, dan itu yang aku butuhkan sebagai pendampingku," Kilah Darma." Oetoro \& Dwiyana, 2015: 174).

Kutipan data di atas menunjukan bahwa kelas sosial, ekonomi, pendidikan, lebih rendah. Diar merasa tidak pantas bersanding dengan pria yang sudah lulus sarjana, karena tidak berpendidikan tinggi dan seabagi bekas pekerja lonte atau pelacur. Namun, hal itu dibantah oleh sahabatnya yang bernama Darma. Manusia memang berbeda tapi tergantung dari niat dan belajar untuk keberhasilan hidup sejahtera. Seperti yang disampaikan Kate Millet bahwa suatu sistem kasta yang menggolongkan tiap individu dengan kelas, mengajak rakyat memiliki semangat hidup yang lebih tinggi untuk mendapatkan kelas sosial yang lebih tinggi pula. Posisi perempuan bisa lebih tinggi dari laki-laki. pada kelas sosial, ekonomi, pendidikan yang lebih tinggi dengan cara sungguhsungguh dan berusaha.

\section{Ekonomi dan Pendidikan dalam Tokoh Diar dalam Novel Rembang Jingga karya Tj Oetoro dan Dwiyana Premadi}

Dalam patriarki tradisionaal, perempuan sebagai manusia tidak diizinkan untuk bereksistensi di bidang ekonomi, baik secara laus ataupun haknya sendiri. Apalagi perempuan bekerja di sosial patriarki. Mereka sering mengerjakan rutinitas atau bahkan tugas yang berat tetapi tenaga mereka tidak dipandang sebagai buruh atau tenaga kerja. Mereka diberi gaji atas dasar penghargaan ekonomi pada patriarki modern. Perempuan memiliki hak atas ekonomi ketika mereka bekerja dan berhak mendapatkan gaji (Millet, 1970:39).

Sejak perempuan memiliki kebebasan dalam kehidupan ekonomi, agen-agen memberikan petunjuk tentang semua hal (kepercayaan, psikologi, periklnan dan lainnya) secara berkelanjutan menegur atau bahkan melawan kedudukan perempuan kelas menegah. Akan tetapi, menurut Millet, pekerjaan apapun yang dimiliki perempuan, mereka tetap memliki pekerjaan ganda, yakni mnegurus anak dan rumah tangga dan pekerjaan yang dimilikinya itu.

Semenjak pendidikan dan ekonomi berhubungan erat dalam kemajuan bangsa. Hal tersebut signifikan dengan level umum dan tingginya pendidikan peerempuan sehingga juga dapat menduduki jabatan yang diinginkan. Sebagai seorang perempuan, Diar berhak mendapatkan kebebasan dalam kehidupan ekonomi dan pendidikan, ketika bekerja, mereka berhak mendapatkan gaji. Bahkan menjadi agen-agen memberikan petunjuk tentang semua hal (kepercayaan, psikologi, periklnan dan lainnya) seperti kutipan berikut.

Diar cukup berhasil meniti karir sebagai pekerja warung tegal dia bahkan sudah diserahi warung sendiri, yang membawahi beberapa perempuan bekerja.Warung yang dikelola Diar kemudian menyediakan menu pecel ayam dan pecel lele, masakan lamongan.Warungnya laku keras, apalagi bersebelahan deangan warung rokok dekat perumahan dan sebuah sekolah kejuruan." (Oetoro dan Dwiyana, 2015: 92)

Kutipan data di atas menunjukan bahwa perempuan bisa bekerja di bidang ekonomi bahkan bisa saja memberikan lapangan pekerjaan terhadap perempuan yang lain. Diar diberi kepercayaan bahwa dia mampu menjalankan usaha dan memajukan ekonomi masyarakat sekitar. Seabagai seorang perempuan berhak meniti karir dan 
menempuh pendidikan tinggi. Namun tidak dengan Diar, dia berhenti sekolah sejak memasuki kelas 2 SMP dan dijemput ayahnya untuk bekerja di warung miliknya. Dengan adanya ini seakan perempuan tidak berhak melanjutkan sekolah yang lebih tinggi. Padahal dalam teori Kate Millet dijelaskan perempuan mampu menduduki kasta tinnggi baik di bidang pendidikan maupun ekonomi asalkan perempuan diberikan kebebasan. Diar mengajak temanya yang bernama Ires untuk menempuh pendidikan. Dengan hal itu pekerjaan Ires semakin bertambah belajar dan mengurus rumah tangga. Setelah mereka bebas dari siksaan seorang laki-laki mereka memanfaatkan kesempatan untuk belajar.

\section{Paksaan terhadap tokoh Diar dalam Novel Rembang Jingga karya T.j Oetoro dan Dwiyana Premadi}

Sistem patriarki secara historis memiliki instusi penekanan melalui sistem legal mereka. Contohnya pada sistem patriarki yang ada dalam islam, telah mengimplementasi larangan melawan legimitasi atau ekonomi seksual dengan kalimat mematikan. Paksaan patriarki juga mempercayakan pada kekerasan seksual yang istimewa dalam karakter dan menyadari secara penuh dalam aksi perkosaan. Hal tersebut dikarenakan kaum laki-laki mengangap kaum perempuan sebagai kaum yang subordinat, juga karena kekuatan fisik mereka yang lebih kuat (Millet, 1970:43).

Cerita dalam sebuah karya sastra baik langsung maupun tidak langsung pasti berhubungan dengan dunia nyata dan berhubungan dengan penulis dan sekitarnya atau kehidupan nyata yang berhubungan dengan waktu dan tempat yang sama. Begitu juga dengan novel yang berjudul Rembang Jingga ini yang mengisahkan tokoh Diar yang mengalami pemaksaan oleh ayah kandungnya sendiri. la dipaksa menjadi pelacur atau lonte dengan menjual badannya kepada seorang laki-laki hidung belang demi kesenangan dan memenuhi kebutuhan hidupnya. Paksaan yang terjadi seperti kutipan data berikut.

Sudah sekitar setahun Diar tinggal bersama Bapak dan Si Mbok di wilayah pantura kabupaten Rembang ini.Awalnya Diar sekedar membantu si Mbok Endang di warung.Melakukan pekerjaan-pekerjan rumah tangga seperti biasa.Namun, sekitar dua bulan lalu, tiba-tiba ayahnya melancarkan aktivitas cabul itu.Diar dipaksa melayani kebutuhan seks para laki-laki hidung belang (Oetoro dan Dwiyana, 2015:57).

Kutipan data data di atas merupakan bukti paksaan yang terjadi dalam tokoh Diar. Diar dipaksa melayani kebutuhan seks para laki-laki hidung belang oleh ayah kandungya sendiri yang tidak memikirkan perasaan anaknya. Ayah Diar hanya mementingkan kesenangan dan kebutuhannya. Tokoh Diar dipaksa harus mengenakan pakaian yang seksi dan berdandan secara glamor yang seharusnya tidak harus ia lakukan. Tanpa berpikir panjang apapun yang diperintah oleh sang ayah pasti Diar turuti meskipun itu menjatuhkan dirinya. Diar dipekerjakan sebagai PSK. Bahkan Diar mendapatkan tamparan dari ayahnya yang membuat dia harus menurut dan tidak berkutik. Hal ini sangat berkaitan dengan teori yang disampaikan Kate Millet. kaum lakilaki mengangap kaum perempuan sebagai kaum yang subordinat, juga karena kekuatan fisik mereka yang lebih kuat sehingga memaksa perempuan dengan menggunakan fisiknya. Diar dipaksa menjual keperawananya oleh seorang ayah yang tanpa memilih laki-laki yang akan Diar layani. Setiap ada sopir yang berhenti ayahnya selalu menyuruh Diar untuk melayani. Paksaan patriarki juga mempercayakan pada kekerasan seksual yang istimewa dalam karakter dan menyadari secara penuh dalam aksi perkosaan. Hal tersebut dikarenakan kaum laki-laki mengangap kaum perempuan sebagai kaum yang subordinat, juga karena kekuatan fisik mereka yang lebih kuat. 
Betapa Diar meronta-ronta sekuat tenaga. Betapa setiap rontaanya justru semakin membuat sesuatu pada laki-laki itu menancap tajam tubuhnya. Semakin meronta, semakin dalam. Laki-laki itu pun seperti semakin beringas semakin terpuaskan dengan setiap rontaan Diar (Oetoro dan Dwiyana, 2015:60).

Kutipan data di atas merupakan paksaan seksual terhadap Diar. Diar merontaronta sekuat tenaga untuk bebas tetapi apa daya laki-laki tersebut semakin terpuaskan dengan rontaan Diar. Hal ini berkaitan dengan teori yang disampaikan Kate Millet. Paksaan patriarki juga mempercayakan pada kekerasan seksual yang istimewa dalam karakter dan menyadari secara penuh dalam aksi perkosaan. Hal tersebut dikarenakan kaum laki-laki mengangap kaum perempuan sebagai kaum yang subordinat, juga karena kekuatan fisik mereka yang lebih kuat. Perilaku seorang ayah memaksa kehendak anaknya ketika tidak mengikuti apa perintahnya. Kekuatan laki-laki dan perempuan memang sangat berbeda. Perempuan hanya sebagai budak bagi laki-laki tanpa memikirkan psikologis seorang perempuan. Hal ini berkaitan dengan teori yang disampaikan Kate Millet kaum laki-laki mengangap kaum perempuan sebagai kaum yang subordinat, juga karena kekuatan fisik mereka yang lebih kuat sehingga memaksa perempuan dengan menggunakan fisiknya. Diar dipaksa untuk ganti baju dan berdandan karena di waktu siang itu ada tamu yang harus dilayaninya. Diar tidak berani membantah perintahnya, karena setiap kali Diar membantah ayahnya pasti marah bahkan ditampar. Hal tersebut dikarenakan kaum laki-laki mengangap kaum perempuan sebagai kaum yang subordinat

\section{Antropologis (mitos dan kepercayaan) Tokoh Diar dalam Novel Rembang Jingga karya T.j Oetoro dan Dwiyana Premadi}

Fakta-fakta dari antropologi, kepercayaan dan semua mitos memeberikan kebijaksaan secara politik karakter tentang keyakinan tentang perempuan. Seorang antropolog menyerahkan kepada sebuah nada patrirki yang kosisten dari asumsi bahwa biologis perempuan berbeda dalam pemisahannya. Di bawah patriarki, perempuan tidak dapat menegmbangkan sendiri simbol-simbol yang mereka diartikan (Millet, 1970:46). Pada upacara-upacara kebudayaan juga kebanyakan dipimpin bahkan dijalankan oleh kaum laki-laki. Perempuan dianggap najis dan kotor. Perasaan atau feeling yang dimilki perempuan dianggap tidak murni atau dibuat-buat.

Pada cerita-cerita lama, banyak mengisahkan kehidupan-kehidupan sebelum dan sesudah tibanya perempuan di bumi. Mereka percaya bahwa perempuan hanya memberi kenikmatan sesaat bahkan di bumi bagian timur. Zaman dahulu apabila lahir bayi perempuan maka akan dibunuh pada saat itu juga. Millet juga mengambil kisah Adam and eve, yakni cerita islami tentang Nabi Adam yang diturunkan ke bumi karena terkena godaan hawa memakan buah terlarang. Secara luas, patriarki beranggapan bahwa ada hubungan yang kuat antara perempuan, seks, dan dosa. Berdasarkan aspek ketiga itu menjadi pola fundamental dari pemikiran patriarki barat.

Dalam novel Rembang Jinnga karya Tj Oetoro dan Dwiyana Premadi ada seorang tokoh yang bernama Agus yang beranggapan bahwa seorang laki-laki terpakai dalam kegiatan keagamaan. Secara tidak langsung beranggapan bahwa perempuan tidak bisa memimpin dalam kegiatan keagamaan Hal itu tampak pada kutipan berikut ini.

\footnotetext{
"Ternyata laki-laki tetap laki-laki ya, Yar, terpakai untukk kegiatan keagamaan yang hanya bisa dilakukan laki-laki"

"Maksudmu apa to, Gus?"

"Maksudku walaupun aku ngak Macho."

"Oooh itu. Ah sudahlah, kurasa dimata Tuhan, laki-laki yaa laki-laki nggak pakai walaupun, nggak pakai tapi” (Oetoro dan Dwiyana, 2015: 53).
} 
Dalam kutipan data di atas menunjukan bahwa laki-laki sebagai pemimpin keagamaan dan hanya bisa dilakukan oleh laki-laki. Hal tersebut selaras dengan apa yang dikatakn Kate Millet. Fakta-fakta dari antropologi, kepercayaan, dan semua mitos memeberikan kebijaksaan secara politik karakter tentang keyakinan tentang perempuan. Pada upacara-upacara kebudayaan juga kebanyakan dipimpin bahkan dijalankan oleh kaum laki-laki. Perempuan dianggap najis dan kotor. Perasaan atau feeling yang dimiliki perempuan dianggap tidak murni atau dibuat-buat.

\section{Psikologis Tokoh Diar dalam Novel Rembang Jingga karya T.j Oetoro dan Dwiyana Premadi}

Aspek-aspek patriarki sudah dideskripsikan dalam bentuk pengaruh psikologis dari kedua jenis kelamin. Akibat secara prinsipal ialah interioritasi ideologi patriarki. Status, emosi, dan peranan marupakan sistem nilai dengan percabangan psikologis yang tak ada habisnya untuk setiap jenis kelamin. Perkawinan patriarki dan keluarga dengan bagian-bagian besar dalam penyelengaraan mereka. Laki-laki menduduki posisi ekonomi yang superior sedangkan perempuan sebagai kaum inferior yang dimplikasinya terkubur. Perempuan yang dianggap patriarki, kelompok yang termaginalkan, juga masih dianggap sebagai kelompok minoritas. Anggapan tersebut dikarenakan fisik atau karakteristik budaya mereka sedikit berbeda dengan yang lainnya. Dapat dikatakan, patriarki adalah senjata psikologis terhebat karena mampu mempengaruhi psikis seorang secara langsung ataupun tidak langsung (Millet, 1970:54).

Permasalahan psikologis yang terjadi pada tokoh Diar berada pada tekanan batin. Tubuh seorang anak dijadikan sebagai ladang untuk mencari uang sehingga sering kali menganggu psikologisnya. Hidupnya tertekan kerena harus menuruti semua kemuan ayah kandungnya. Seorang ayah yang tidak pernah memikirkan psikis dan psikologis anak kandungnya sendiri.

Dilihatnya si Mbok duduk di tepi tempat tidur, mengguncang-guncang tubuh Diar. Rupanaya Diar mimpi buruk. Mimpi buruk yang hadir hampir setiap malam dalam tidurnya. Diar langsung bangun dan duduk atas tempat tidur reyotnya, berelaskan kasur tipis berlapis sprei lapuk. Napasnya memburu, keringat bercucuran membasahi baju dan rambutnya.

"Ono opo, Nduk? Ngimpi maneh toh?" tanya si Mbok memastikan bahwa Diar mengingau karena mengalami mimpi buruk lagi, sambil mengusap-ngusap wajah Diar penuh peluh. Tangan kurus iti kemudian menyodorkan segelas air (Oetoro dan Dwiyana, 2015:53).

Kutipan tersebut merupakan permasalahan psikologis yang terjadi pada Diar. Tekanan yang terjadi pada alam bawah sadar karena merasa ketakutan akan kekerasan yang menimpa dirinya. Dian selalu dihampiri makhluk-makhluk aneh pada malam hari dan selalu datang pada waktu tidur malamnya. Hal tersebut membuat Diar ketakutan saat tidur. Hakikat mimpi dalam psokologi hanyalah bentuk pemenuhan keinginan terlarang semata. Individu secara tidak sadar berusaha memenuhi hasrat dan menghilangkan ketegangan dengan menciptakan gambaran tentang tujuan yang diinginkan kareana di alam nyata sulit bagi kita untuk mengungkapkan kekesalan, keresahan, kemarahan, dendam, dan sejenisnya. Setiap hari harus melewati rasa sedih yang teramat dalam akan perbuatan yang dia lakukan. Kekerasan yang terjadi sulit dilupakan sehingga selalu menghantui pikirannya. Rasa sakit bukan hanya pada tubuh Diar melainkan pada batinya pula. Menangis dan meratapi nasib itu yang harus dialami oleh perempuan tersebut. 
Diar merasakan kesakitan dan kepahitan dalam hidupnya. Tamparan yang dilontarkan oleh orang tua kandung sendiri membuat Diar tak kuasa menahan perih kehidupan. Kehidupan bersama orang tua yang begitu kejam, merelakan anak kandung sendiri hanya demi kesenangan sendiri tanpa memikirkan perasaan seorang anaknya. Hal ini berkaitan dengan teori yang disampaikan Kate Millet Status, emosi, dan peranan marupakan sistem nilai dengan percabangan psikologis yang tak ada habisnya untuk setiap jenis kelamin. Perkawinan patriarki dan keluarga dengan bagian-bagian besar dalam penyelengaraan mereka. Laki-laki menduduki posisi ekonomi yang superior sedangkan perempuan sebagai kaum inferior yang dimplikasinya terkubur.

Diar selalu merasa terganggu, jijik, kotor, dan hina karena melakukan perbuatan kotor yang dipaksa ayahnya dalam sehari-harinya. Diar yang selalu melakukan rutiniatas salat lima waktu dalam seharinya tetapi hatinya masih dilanda rasa bimbang akan perbuatan-perbuatan yang dilakukannya pada malam harinya. Begitu kejam perlakuan ayahnya yang tidak pernah memikirkan keberadaanya. Diar ingin sekali seperti teman-temannya di luar sana yang bebas berkreasi dan bermain serta belajar demi mencapai cita-cita yang telah ditanam sejak dini. Semua itu membuatnya selalu terbayang-bayang dalam mimpi setiap malamnya. Bila ia juga ingin bebas seperti mereka yang tak punya beban hidup dan pekerjaan yang menjijikkan di usia mereka yang di usia dini. Dalam waktu shalat dan mandi dia selalu memikirkan bagaimana cara untuk kabur dari rumahnya. Namun, pikirannya selalui dihantui rasa takut. Laki-laki yang jarang bicara tetapi wajahnya sangat menakutkan membuatnya harus terpikirkan dan menjadi beban bagi kehidupannya.

\section{SIMPULAN}

Novel Rembang Jingga yang ditulis oleh Tj Oetoro dan Dwi Premadi menarik untuk diteliti karena banyak mengandung motivasi, inspirasi, dan nilai perjuangan oleh tokoh-tokoh yang berada di dalamnya. Novel Rembang Jingga menceritakan tentang empat tokoh perempuan yang mempunyai masalah yang berbeda-beda. Namun, dari empat tokoh tersebut, tokoh Diar menjadi tokoh yang paling dominan dalam kisah dan perjuangan hidupnya.

Penelitian ini menggunakan teori feminisme Katte Millet dengan delapan konsep, yaitu ideologis, biologis, sosiologis, kelas. ekonomi dan pendidikan, paksaan, antropologis (mitos dan kepercayaan), serta psikologis. Secara ideologis, tokoh Diar dalam novel Rembang Jingga karya Tj Oetoro dan Dwi Premadi memiliki pandangan berani. Hal itu tidak lepas dari paksaan dan biologisnya yang terus dipaksa dan disiksa oleh ayahnya untuk menjadi pelacur. Keberanian tokoh Diar tidak lepas dari faktor sosiologis keluarga yang menjadi penentu hidupnya. Nenek/ Mbah Diar memiliki pengaruh besar dalam mengajarkan prinsip-prinsip hidup menjaga etika dan pendorong semangatnya menjadi manusia yang baik dan juga selalu menanamkan rasa hormat kepada orang tua. Namun, di sisi lain kehendak ayahnya memaksa Diar menjadi perempuan penghibur.

Dalam tataran kelas berdasarkan teori Millet, Diar merasa berada dalam kelas yang rendah karena dia tidak sekolah tinggi dan bekas pekerja lonte atau pelacur. Padahal, pendidikan dan ekonomi berhubungan erat dalam kemajuan bangsa. Hal tersebut signifikan dengan level umum dan tingginya pendidikan peerempuan sehingga juga dapat menduduki jabatan yang diinginkan. Sebagai seorang perempuan, Diar berhak mendapatkan kebebasan dalam kehidupan ekonomi dan pendidikan, ketika bekerja, mereka berhak mendapatkan gaji. Dalam novel tersebut terdapat tokoh Agus yang memiliki kepercayaan antropologi bahwa seorang laki-laki terpakai dalam kegiatan keagamaan. Secara tidak langsung beranggapan bahwa perempuan tidak bisa memimpin dalam kegiatan keagamaan. Berbagai permasalahan kehidupan yang dialami Diar menimbulkan permasalahan psikologis. Hal itu berdampak pada gangguan 
kejiwaannya. Diar sering mengalami mimpi buruk akibat tekanan batin. Tubuh seorang anak dijadikan sebagai ladang untuk mencari uang sehingga sering kali menganggu psikologisnya. Secara generalisasi, feminisme radikal yang digagas Katte Millet relevan dengan novel Rembang Jingga karya Tj Oetoro dan Dwi Premadi.

\section{DAFTAR RUJUKAN}

Departemen Agama. (2016). Al-Quran Tafsir Perkata Tajwid Kode Angka. Tanggerang Selatan: PT Kalim.

Kusharyanto, Juliasih. (2009). Potensi Perempuan Amerika Tinjauan Feminisme. Yogyakarta: Gadjah Mada University Press.

Luxemburg, Jan Van dkk. (1986). Pengantar Ilmu Sastra.Jakarta: Gramedia.

Meleong, Lexy J. (2017). Metodelogi Penelitian Kualitatif. Bandung: PT Remaja Rosdakarya, 2017.

Millet, Kate. (1970). Sexual Politics.Garden City: NY. Doubleday, 1970.

Oetoro, Tj dan Dwiyana Premadi. (2015). Rembang Jingga. Jakarta: Gramedia Pustaka Utama, 2015

Ratna, Nyoman Kutha. (2004). Teori Metode dan Teknik Penelitian Sastra. Yogyakarta: Pustaka Pelajar.

Rokhmansyah, Alfian. (2014). Studi dan Pegkajian Sastra.Yogyakarta: Graha Ilmu.

Sanjaya, Wina. (2013). Teori, Penelitian pendidikan Jenis, Metode dan Prosedur.Jakarta: Kencana Prenada Media Group.

Suharto, Sugihastuti. (2016). Kritik Sastra Feminis Teori dan Aplikasinya. Yogyakarta: Pustaka Pelajar.

Susanto, Edi. (2017). Studi Hermeneutika Kajian Pengantar. Depok: Kencana.

Tong, Rosemarie Putnam. (1998). Feminist Thought Pengantar Paling Komprehensif Kepada Arus Utama Pemikiran Feminis.Yogyakarta: Jalastra. 